\title{
相似則に基づいた大気境界層における 水平乱流場の分類 \\ CLASSIFICATION OF HORIZONTAL TURBULENT STRUCTURE IN TERMS OF SIMILARITY LAW
}

\author{
八木綾子 1 ・稲垣厚至 2 ・神田 学 $3 \cdot$ 藤原忠誠 4 ・藤吉康志 5 \\ Ayako YAGI, Atsushi INAGAKI, Manabu KANDA, Chusei FUJIWARA, and Yasushi FUJIYOSHI \\ 1学生会員 東京工業大学 理工学研究科国際開発工学専攻（广152-8552 目黒区大岡山2-12-1） \\ 2正会員 工博 東京工業大学助教 理工学研究科国際開発工学専攻（同上） \\ 3正会員 工博 東京工業大学教授 理工学研究科国際開発工学専攻（同上） \\ 4 非会員 博(環境科学) 気象研究所気象衛星・観測システム研究部（†305-0052 茨城県つくば市長峰1-1） \\ 非会員 理博 北海道大学低温科学研究所教授（广060-0819 札幌市北区北19条西8丁目）
}

\begin{abstract}
Horizontal turbulent flow fields within atmospheric boundary layer above an urban area (Tokyo, Japan) measured by Doppler lidar in autumn and winter were visually classified into six groups, Streak, No streak, Mixed, Fish net, Front, The others. The conditions of each flow occurrence were examined with observed surface meteorological data and related scaling parameters. The following results were obtained: (1)Streak dominates $64 \%$ of all valid data, while Fish net does only $2 \%$. No streak and The others, look more laminar rather than turbulent, reach to $20 \%$ contribution in total. (2) Each flow patterns can be categorized by $-z_{i} / L$ and $\operatorname{Re}\left(z_{i}\right.$ is boundary layer height, $L$ is the Monin Obukhov length. $R e$ is Reynolds number, the length scale of which is $z_{i}$.). (3) Each flow patterns can be categorized by $-z / L$ and $\operatorname{Re}_{\text {suf }}$ ( $z$ is observation height. $R e_{\text {surf }}$ is Reynolds number, the length scale of which is $z_{i}$.)

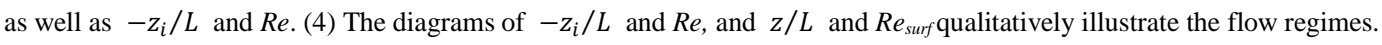

Key Words : Atmospheric boundary layer, Similarity theory, Doppler lidar, Turbulent structure

\section{1. はじめに}

大気境界層の流れ場は, 水蒸気・熱・物質輸送を担っ ており，大気污染やヒートアイランド現象等の大気環境 問題の解決において重要な役割を果たす. 既往研究によ り, 水平ロール渦 ${ }^{122}$, ストリーク構造 ${ }^{3)}$, セル状対流 24), ダストデビル5)等の大気境界層における特徵的な流れ場 の構造が明らかになりつつある. しかしながら，大気境 界層の長期に渡る連続観測・解析は少なく, 大気境界層 における流れ場の全体像は十分にわかっていない.

本研究では, ドップラーライダー (以下, ライダー) および超音波風速計によって得られた長期間の実測デー タから, 都市上空の大気境界層における流れ場の特性 (出現頻度, 出現時の大気場の特徵) を明らかにする. 高時空間解像度で視線方向風速および信号対雑音比（以 下，SNR）の3次元分布を取得可能なライダーの特性を 活かし, 大気境界層（地上高42 m) の水平乱流構造を目 視で詳細に分類する. 目視分類は, アルゴリズムによる 分類よりも客観性は劣るが, 風向・風速・流れ場の組織
的構造が複雑に変化する大気境界層の水平乱流構造を的 確に判別・分類するには最善の手法である. 既に八木ら ${ }^{6}$ はライダーによって観測された大気境界層の水平構造 の目視分類を行っているが，本研究は以下の 2 点におい て新しい.

まず，1）より詳細な枠組みによる分類を行う．ライ ダーによる常時観測から, 既往研究で着目されているス トリーク構造やセル状対流とは異なる流れ場が度々確認 された.これらの流れ場には再現性があり, 大気境界層 の流れ場を分類する上で重要であると判断し, 流れパ ターンとして分類枠組みに新たに加えた.

次に，2）相似則に基づき，境界層のスケーリングパ ラメタと流れパターンの関係を議論する. 既往研究にお いて，大気境界層における特徵的な流れ場の発生条件は， 大気安定度 $\left(-z_{i} / L\right)$ で説明されてきた 7$) .-z_{i} / L$ は, 大気境界層における流れ場の説明変数として欠かせない が，慣性力の効果を含まない，そこで，本研究では慣性 力も大気境界層の流れ場に影響を与えていると考え， $-z_{i} / L$ に加えてレイノルズ数 $(R e)$ を説明変数に加えた. 


\section{2. 観測 - 解析概要}

\section{(1) 観測概要}

\section{a) 観測サイト}

東京都目黒区でライダーおよび超音波風速計を用いて 観測を実施した。観測地周辺は住宅地が拡がる市街地で ある. ライダーは目黒区東京工業大学構内の建物屋上

（地上高42 m) に設置し，超音波風速計はライダーの設 置地点から北西に500 $\mathrm{m}$ 離れた建物屋上（地上高 $25 \mathrm{~m}$ ） に設置した.

\section{b) ライダーおよび超音波風速計}

ライダーの諸元を表-1に示す。本研究では，三菱電機 LR-02A，3次元コヒーレントドップラーライダーを使用 した. ライダーは近赤外 $(1.54 \mu \mathrm{m})$ のパルスレーザー を用い，大気中に浮遊するエアロゾルによる後方散乱の ドップラーシフトから，視線方向風速およびSNRを高時 空間解像度で測定する. 視線方向分解能は50 m, 観測レ ンジは325 m から4275 m である. 方位角分解能はパル ス繰り返し周波数，積分回数，スキャンスピードで決ま り，本観測のパラメタ設定では約 1.2 ○である．走査スケ ジュールは，水平スキャン (Plan Position Indicator, PPI) および鉛直スキャン（Range Height Indicator, RHI）を交 互に行う30分間のシークエンスを繰り返した.

超音波風速計はクリマテック CYG81000，3成分超音 波風速計を使用し，サンプリング周波数 $10 \mathrm{~Hz}$ で風速3成 分および気温を計測した。

\section{(2) 目視分類}

\section{a) 分類基準}

ライダーによって観測されたPPI画像（視線方向風速 の空間分布）を表-2の基準によって分類した. 本研究で 新たに加えた分類枠組みは，2. No streak, 3. Mixedである 分類指標となっている視線方向風速が $0 \mathrm{~m} \mathrm{~s}^{-1}$ となる線

（図-1の赤色と青色の境目）は主流風向に直交する方向 に走る．例えば，観測領域内で風向が一様な場合，視線
方向風速が $0 \mathrm{~m} \mathrm{~s}^{-1}$ となる線は主流直交方向の直線となる.

図-1に各流れパターンのPPI画像を示す. 図-1のa1の 筋の幅が細いStreakはシア不安定により生じるストリー クに対応し，図-1のa2の筋の間隔が広いStreakは水平 ロール渦に対応していると予測されるが，これについて は別途解析を進めている最中である．No streakは主流が 存在するものの筋状のパターンは認められず, 場所に よって細いまだらの微細構造が存在し，層流から乱流 の遷移で見られる乱流斑点（turbulent spot）を予想させ る（図-1のb）。Fish netはセル状の鉛直対流卓越時に見 られる風速分布であり ${ }^{4)}$, MixedはStreakおよびFish netの 中間的な風速分布である.Frontは視線方向風速の不連 続線が時間と共に風下に通過した事例とした。The othersに含まれる事例（図-1のe1, e2）は，視線方向風速 が $0 \mathrm{~m} \mathrm{~s}^{-1}$ となる線の形状も, 視線方向風速のパターンも 多様である.

\section{b) 解析データ}

2012年9月25日から2012年10月20日（以下，秋期）お よび2012年12月1日から2013年1月10日（以下，冬期）の 2期間に，30分あたり7回のPPIスキャンを含むスキャン シークエンスで観測されたPPI画像全てを解析対象とし た．但し，データの品質管理のため，観測半径 $2025 \mathrm{~m}$ の円周上でSNRが $6 \mathrm{~dB}$ 以下となるエラ一值が $10 \%$ 以上の データはError, 降水による欠損データをRainと分類し, 目視分類の解析対象から除外した.

表-1 ドップラーライダーの諸元

\begin{tabular}{ll}
\hline \hline Wavelength & $1.54 \mu \mathrm{m}$ \\
\hline Leaser pulse width & $213 \pm 10 \mathrm{~ns}$ \\
\hline Pulse repetition frequency & $4 \mathrm{kHz}$ \\
\hline Integral number of pulses & 1000 \\
\hline Range resolution & $50 \mathrm{~m}$ \\
\hline Minimum range & $325 \mathrm{~m}$ \\
\hline Maximum range & $4275 \mathrm{~m}^{-1}, 5 \mathrm{~m} \mathrm{~s}^{-1}$ \\
\hline Scan speed (in PPI mode, RHI mode) & $4.5 \mathrm{~m} \mathrm{~s}^{-1}$ \\
\hline \hline
\end{tabular}

\section{表-2 ライダーにより観測されたPPI画像（視線方向風速の水平分布）の分類基準}

\begin{tabular}{ll}
\hline \hline 流れパターン & 分類基準 \\
\hline 1. Streak & $\begin{array}{l}\text { 視線方向風速が } 0 \mathrm{~m} \mathrm{~s}^{-1} \text { となる線が直線状であり, 主流風向が一定である. } \\
\text { 視線方向風速分布が主流風向に沿った明瞭な筋状のパターンとなっで. }\end{array}$ \\
\hline 2. No streak & $\begin{array}{l}\text { 視線方向風速が } 0 \mathrm{~m} \mathrm{~s}^{-1} \text { となる線が直線状であり, 主流風向が一定である. } \\
\text { 視線方向風速分布が筋状のパターンとなっていない. }\end{array}$ \\
\hline 3. Mixed & $\begin{array}{l}\text { 視線方向風速が } 0 \mathrm{~m} \mathrm{~s}^{-1} \text { となる線が乱れており直線状ではないが, 主流風向は一定である. } \\
\text { 視線方向風速分布が䇗状のパターンとなっているが, } 1 . \text { Streakと比べると不明瞭である. }\end{array}$ \\
\hline 5. Front & 視線方向風速が正の領域と負の領域が入り混じっており, 主流風向が定まらない. \\
\hline 6. The others & 視線方向風速分布の不連続線が存在し, 不連続線が時間と共に風下に移動する. \\
\hline \hline
\end{tabular}


a1) Streak

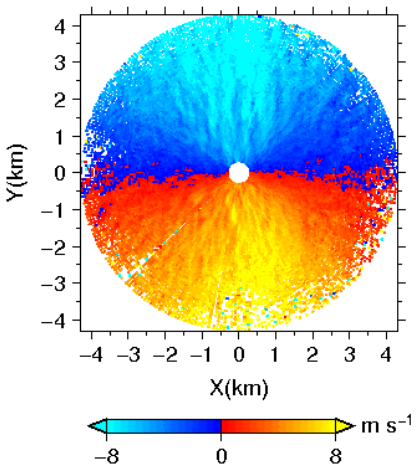

d) Fish net

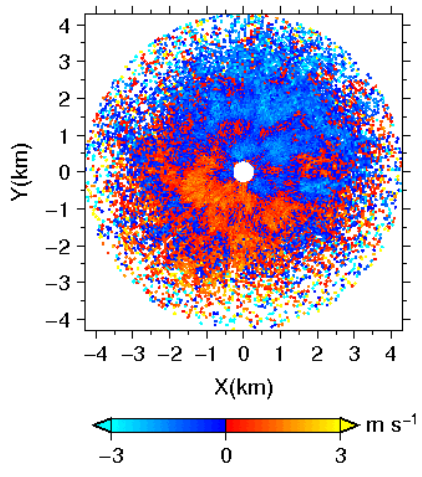

a2) Streak

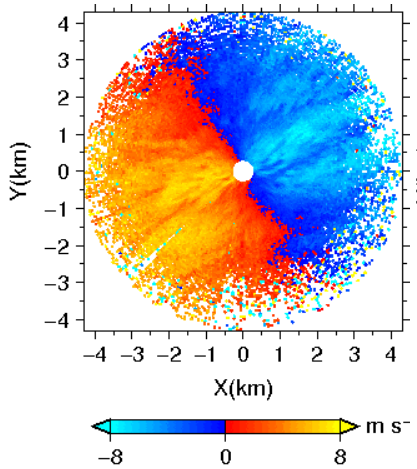

e) Front

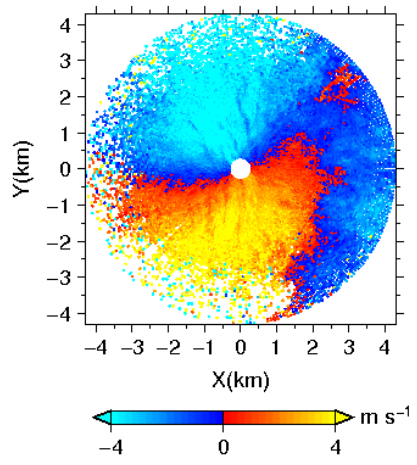

b) No streak

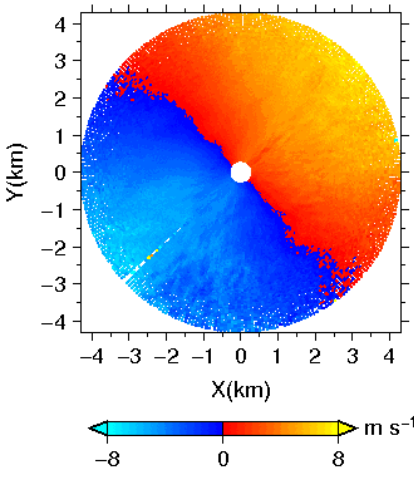

f1) The others

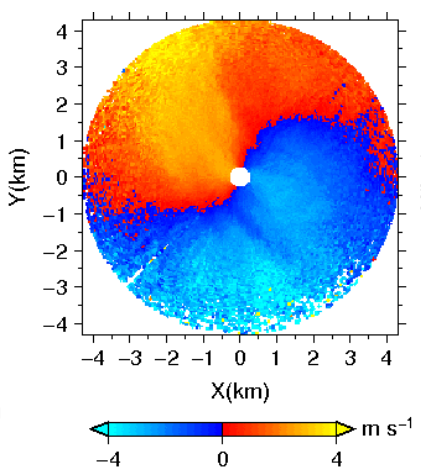

c) Mixed

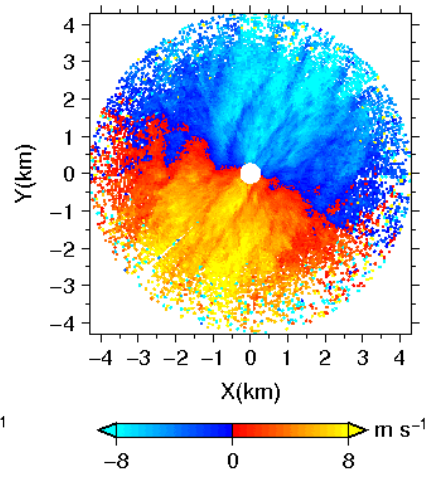

f2) The others

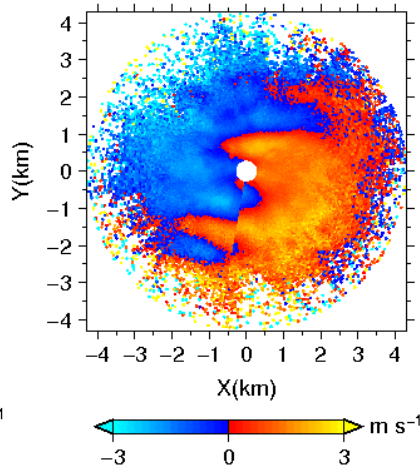

図-1＼cjkstart各流れパターンのPPI画像（視線方向風速の水平分布）の例

(3)パラメタの算出

\section{a) 摩擦速度および摩擦温度}

摩擦速度 $\left(u^{*}\right)$ および摩擦温度 $\left(T^{*}\right)$ は超音波風速 計によって観測された風速3成分および気温に渦相関法8) を適用し，式(1)(2)から算出した。

$$
\begin{gathered}
u^{*}=\left(-\overline{u^{\prime} w^{\prime}}\right)^{1 / 2} \\
T^{*}=-\overline{T^{\prime} w^{\prime}} / u^{*}
\end{gathered}
$$

ここで， $u^{\prime} ， w^{\prime} ， T^{\prime}$ は，主流風速，鉛直風速，気温の30 分平均值からの変動成分である. 一 する.

\section{b) 大気境界層高度}

大気境界層高度 $\left(z_{i}\right)$ はライダーで観測されたSNRの 鉛直プロファイルにHaar wavelet transform ${ }^{9}$ を適用して推 定した．SNRの鉛直プロファイルは，RHIスキャンに よって観測されたSNRの鉛直平面分布を高度毎に空間平 均して用いた. 空間平均後のSNRの鈆直プロファイルの レンジは，0m -3000m（ライダー設置高度を $0 \mathrm{~m}$ とす る），分解能は50 mである. SNRの鉛直プロファイルを Haar wavelet変換して得られるウェーブレット係数は SNRが急激に減少（増加）する高度でウェーブレット係 数が大きく (小さく) なる. 図-2にSNRの鉛直空間分布 とSNRおよびウェーブレット係数の鉛直プロファイルを 示す. SNRの鉛直空間分布から，高度 $1.6 \mathrm{~km}$ 付近まで エアロゾル濃度が高い大気境界層が発達し， $2.2 \mathrm{~km}$ お よび $2.8 \mathrm{~km}$ 付近に雲が発生している. ウェーブレット
係数は，SNRが急激に減少する大気境界層上端および雲 頂で大きくなり，SNRが急激に増加する雲底で小さく なっている. 一般的に大気境界層上端よりも雲頂の方が SNRの減少幅は顕著なため, ウェーブレット係数は大き な値となる.

本研究では, 雲によってウェーブレット係数が雲頂で 大きくなる場合を考慮し， ウェーブレット係数が最大と なる3高度の中で最も低い高度を $z_{i}$ とするアルゴリズム を用いた，大気境界層が多層構造となる場合，算出され る $z_{i}$ は最も下層の高度となる， $z_{i}$ のレンジは，Haar関数 の空幅（本研究では150 m) およびライダーの観測高度 によって決まり，算出最低高度は $150 \mathrm{~m}$, 最高高度は 2850 mである.

\section{3. 結果と考察}

\section{(1) 各流れパターンの出現傾向}

表-3に各流れパターンの発生回数およびデータ取得率 を示す．データ取得率は，全データ数に対する解析対象 事例数合計の割合である.

発生回数は, Streak, Mixed, The others, No streak, Fish net, Frontの順で多い. 最も多く発生したStreakは解析対 象事例の64\%を占めており, 大気境界層内の代表的な流 れ場と言える. 季節間で比較すると, 秋期よりも冬期の 方がNo streakおよびThe othersの発生率は一桁大きい，一 
方, Streakの発生率は冬期の方が小さい。つまり, No streakおよびThe others とStreakの発生比率が季節に応じて 相互補完的に変化している。. また，秋期に比へ，冬期の Errorの頻度が高い。これは，冬期においてライダーの ターゲットであるエアロゾルの数密度および粒径が小さ くなり，SNRが低くなるためであると考えられる．

図-3に流れパターンの出現頻度および $\overline{W^{\prime} T^{\prime}}$ の日変化 を示す． $\overline{w^{\prime} T^{\prime}}$ は解析期間の平均值である. Streakは時間 帯によらず出現している。，一方，Fish netおよび Mixed は $\overline{W^{\prime} T^{\prime}}$ が正の值となる日中に出現している. No streakお よび The othersは $\overline{W^{\prime} T^{\prime}}$ が負の值となる夜間に出現してい る. 季節間で比較すると, 秋期の $\overline{w^{\prime} T^{\prime}}$ は冬期よりも朝 の早い時間帯から増加し始める。これと対応してMixed およびFish netは秋期の方が朝早い時間帯から発生して いる. また，冬期の $\overline{w^{\prime} T^{\prime}}$ は秋期よりも夕方の早い時間 帯から減少し負の值となる。 これと対応して, No streak およびThe othersは冬期の方が夕方の早い時間帯から発 生している.これらのことから, MixedおよびFish netは 熱フラックスによって駆動され, 正の熱フラックスの供 給が無くなるとNo streakおよびThe othersが発生すると考 えられる.

\section{(2) 大気境界層高度の推定}

秋期において算出した $z_{i}$ および気温の時系列を図-4の (a)に示寸．算出された $z_{i}$ は，気温の上昇と共に高くな り，概衩気温の日変化と矛盾しない時系列変化となって いる. しかしながら, 時系列変化から大きく離れた值と なる $z_{i}$ も見受けられる（図-4（a）の赤円部）。そこで, $z_{i}$ とライダーのRHIスキャンによって観測されたSNRお よび視線方向風速分布の鉛直空間分布を目視で照合し, 鉛直空間分布と整合しない $z_{i}$ は棄却し，最も整合する高 度を他の候補高度から最終推定值として選出した。 $z_{i}$ の 最終推定值を図-4 (b)に示す. 2章で述べたアルゴリズ ムで適当な $z_{i}$ を算出することができなかった事例は，雲

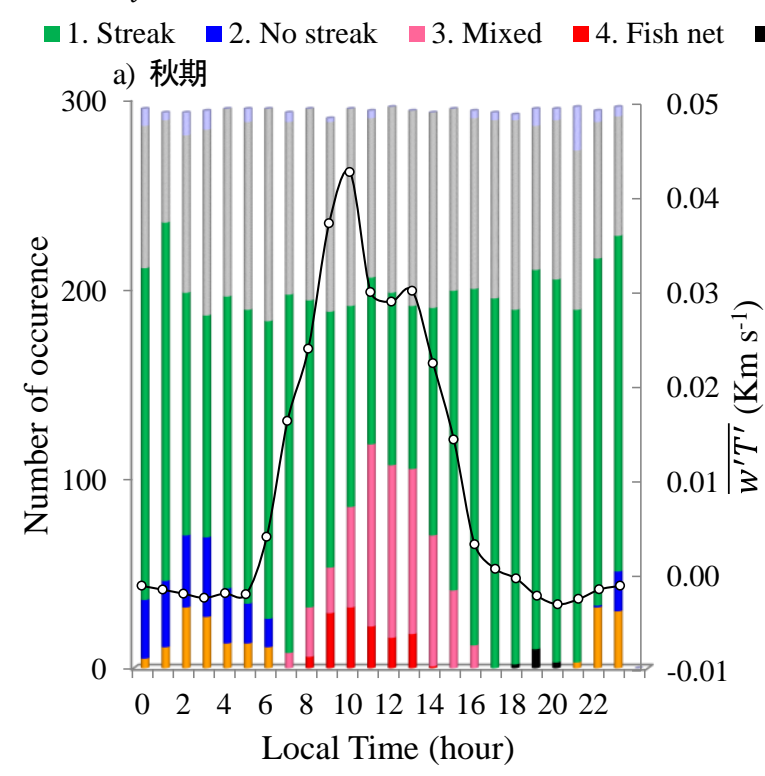

が複数の高度で存在する場合, 夜間において安定層の SNRが残留層よりも小さい場合等であった，また，冬期 においても $z_{i}$ の算出を試みたが大気境界層高度を上手く 見積もることができなかった，これは，冬期において， SNRの值が低く，SNRのピーク值が適切に検出できない ためであると考えられる. なお，以後の議論には目視で 得た最終推定值 $\mathrm{Z}_{\mathrm{i}}$ を用いる.

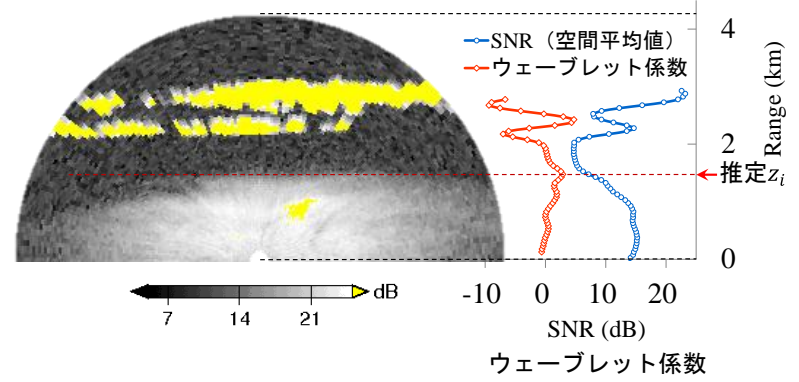

図-2 SNRの鉛直プロファイルとウェーブレット係数の関係 (左図はRHIスキャンで得られたSNRの鉛直空間分布)

表-3 目視分類による各流れ場の発生回数およびデータ取得率

\begin{tabular}{|l|l|l|l|}
\hline \multirow{2}{*}{\multicolumn{1}{|c|}{ 分類 }} & \multicolumn{3}{|c|}{ 発生回数 (発生率) } \\
\cline { 2 - 4 } & $\begin{array}{c}\text { 秋期 } \\
9 / 25 ~ 10 / 15\end{array}$ & $\begin{array}{c}\text { 冬期 } \\
12 / 1 ~ 1 / 10\end{array}$ & \multicolumn{1}{|c|}{ 合計 } \\
\hline \hline 1. Streak & $3,728(78 \%)$ & $1,595(46 \%)$ & $5,323(64 \%)$ \\
\hline 2. No streak & $233(5 \%)$ & $593(17 \%)$ & $826(10 \%)$ \\
\hline 3. Mixed & $507(11 \%)$ & $559(16 \%)$ & $1,066(13 \%)$ \\
\hline 4. Fish net & $124(3 \%)$ & $57(2 \%)$ & $181(2 \%)$ \\
\hline 5. Front & $15(0.3 \%)$ & $8(0.2 \%)$ & $23(0.3 \%)$ \\
\hline 6. The others & $177(4 \%)$ & $670(19 \%)$ & $847(10 \%)$ \\
\hline \hline 解析対象事例合計 & 4,784 & 3,482 & 8,266 \\
\hline \hline 11. Error & $2,163(95 \%)$ & $8,249(98 \%)$ & $10,412(98 \%)$ \\
\hline 12. Rain & $113(5 \%)$ & $140(2 \%)$ & $253(2 \%)$ \\
\hline \hline 非解析対象事例合計 & 2,276 & 8,389 & 10,665 \\
\hline \hline データ取得率 & $68 \%$ & $29 \%$ & $44 \%$ \\
\hline \hline
\end{tabular}

-5. Front $\square$ 6. The others $\approx 11$. Error $\approx 12$. Rain $-0 \overline{w^{\prime} T^{\prime}}$

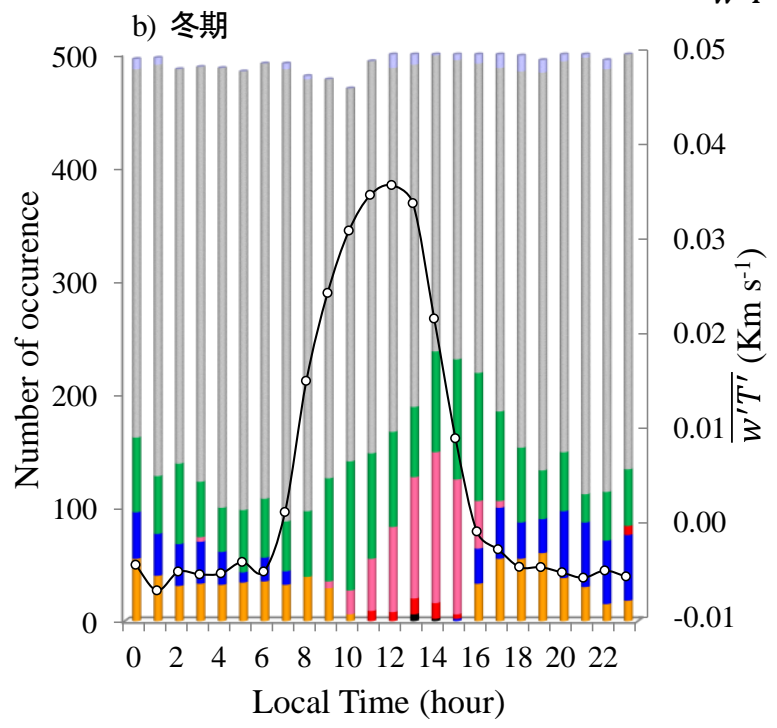

図-3 各流れパターンの発生回数および $\overline{W^{\prime} T^{\prime}}$ の日変化 

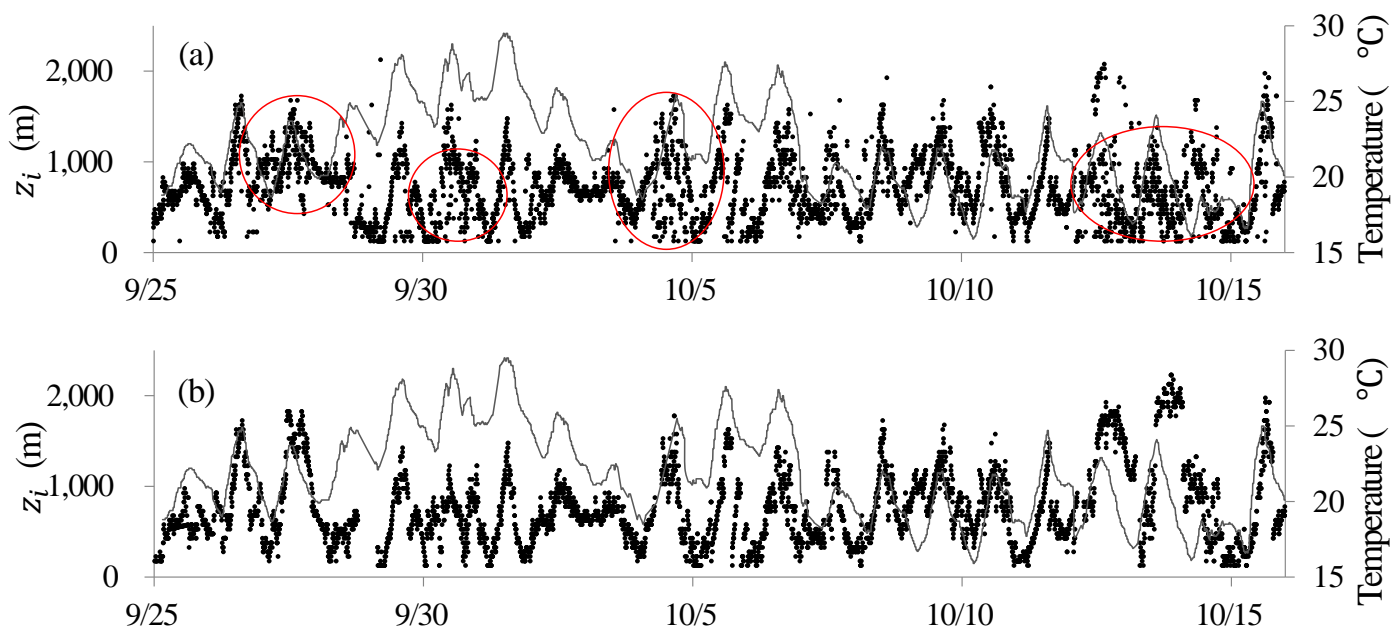

図-4 境界層高度の推定值および気温の時系列変化

((a) 境界層高度の第一推定值，(b)最終推定值を黒い点で，気温を灰色の線で示す)

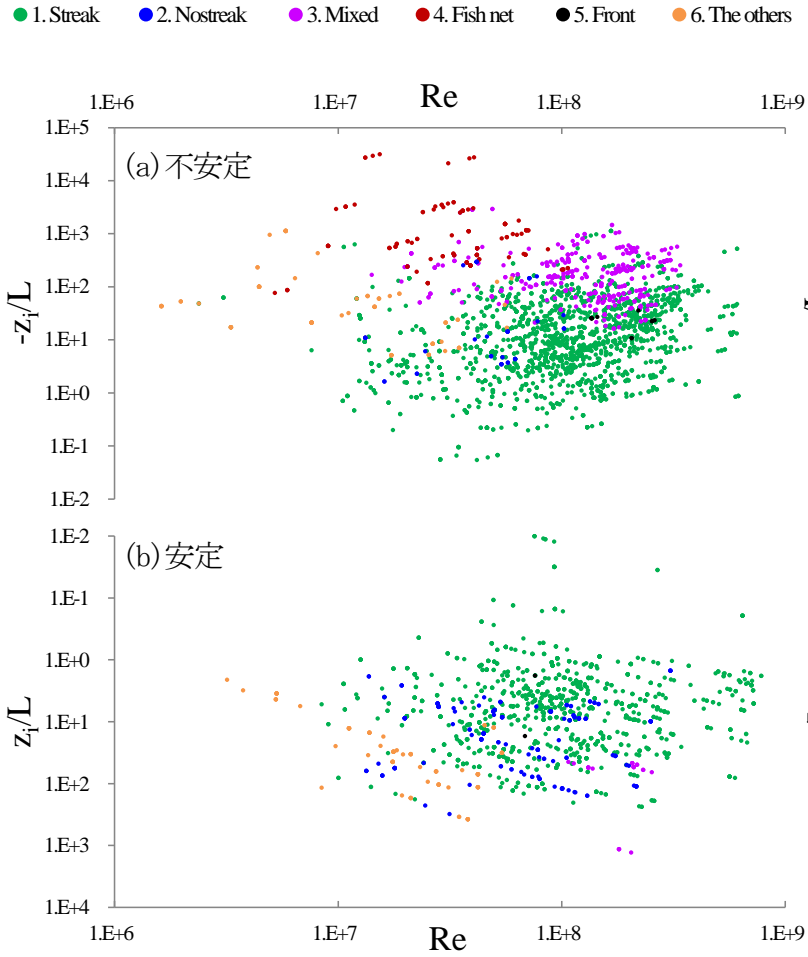

図-5＼cjkstart各流れパターンとReおよびー $z_{i} / L$ の関係 $)$

(3) 相似則パラメタと流れパターンの関係

a) $z_{i}$ を含むレイノルズ数および大気安定度

図-5に秋期のReおよびー $z_{i} / L$ と各流れパターンの関係 を示す（（a）に不安定場，（b）に安定場を対数表示した）。

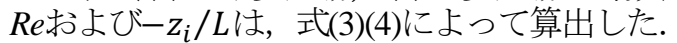

$$
\begin{array}{r}
R e=\frac{U z_{i}}{v} \\
-\frac{z_{i}}{L}=\frac{\mathrm{k}(g / T) T^{*} z_{i}}{u^{* 2}}
\end{array}
$$

ここで，Uは地表面付近の主流風速，vは動粘性係数， $L$ はMonin Obkukovの安定度スケール，kはカルマン定数, $g$ は重力加速度，Tは気温である。 Uおよび $T$ には超音波 風速計による観測值の30分平均值を使用した。 大気乱流 はレイノルズ数が大きく粘性の影響が極めて小さいと考 えられるため，動粘性係数を渦動粘性係数に変えた検討 $\bullet$ 1. Streak $\bullet$ 2. Nostreak $\bullet$ 3. Mixed $\bullet$ 4. Fish net $\bullet$ 5. Front $\bullet$ 6. The others

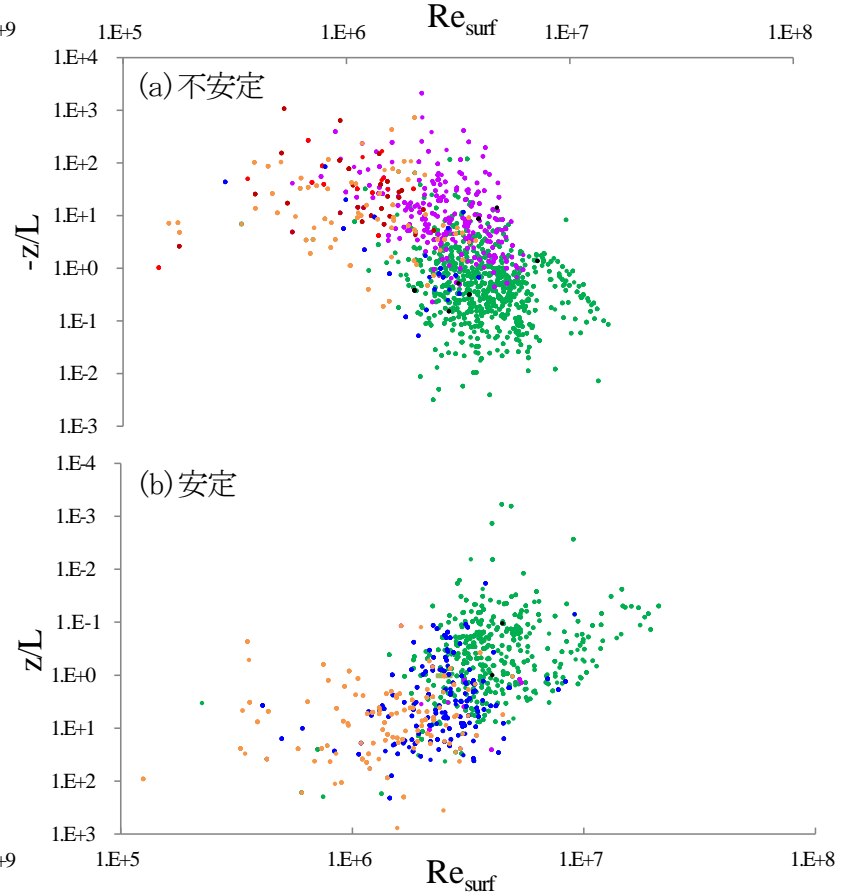

図-6＼cjkstart各流れパターンとR $e_{\text {suf }}$ おびー $z_{i} / L$ の関係 も行ったが，各モードの分類は動粘性係数を用いた場合 に比べ大きく改善しなかったため, より一般的な動粘性 係数を用いた $R e$ で議論する. 図-5より，各流れパター ンが出現する大気場にはそれぞれ特徵があることがわか る．不安定場に着目すると，Streakは大気が中立に近く 慣性力が大きい場で発生する。大気がより不安定になる と，慣性力が強い場でMixedが，慣性力が弱い場でThe othersが発生する。そして，大気がさらに不安定になる とFish netが出現する。安定場において，The othersは安 定度が強く慣性力が小さい場で生じる。これは，地表面 からの機械的および熱的乱流エネルギー供給が極めて小 さい場に相当するが，それでも図-1 (f2)に見られる有意 な乱流変動のパターンが形成される原因として，重力波 やマイクロフロントの様な外部擾乱の影響 (TKEの移流) が考えられる(10)11).さらに，The othersのプロットは右肩 下がりに並んでおり，強い安定度場では，より高いRe でも静穏な流れ場であるThe othersが出現可能であるこ 


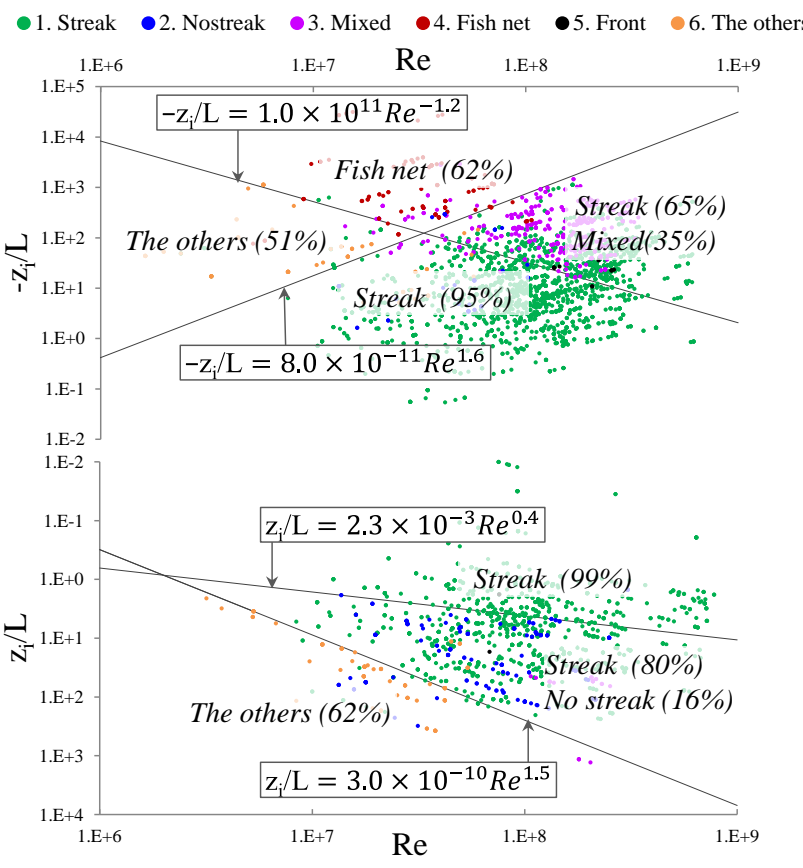

図-7 図-5から得られた流れパターンの発生傾向（点線で 各流れパターンの出現境界を, 各領域内に上位の流れパ ターンおよび領域内の出現頻度を示した.）

とが示唆される．また，No Streakは不安定場および安定 場において，StreakとThe othersの境界に位置し，乱流遷 移状態を予測させる. 図-5から求めた流れ場パターンの 境界および発生傾向を図-7に示す。

流れパターンが出現する大気場は，既往研究で指摘さ れているー $z_{i} / L$ のみならずReにも依存しており,$-z_{i} / L$ およびReを用いて流れ場を整理することで，浮力および 慣性力による乱流エネルギー供給が少ない場で発生する 流れ場 (No streak, The others）の評価が可能となった.

b) 地表面付近を代表するレイノルズ数および大気安定度

図-6に秋期および冬期のR $e_{\text {surf }}$ およびー $z / L$ と各流れ パターンの関係を緾めて示す. Re $e_{\text {surf }}$ およびー $z / L$ は式 (3)(4)において $z_{i}$ の代わりに超音波風速計の地上高 $25 \mathrm{~m}$ を 代入した值であり，地表面付近のローカルな大気場を表 す（なお，前節で議論したパラメター $z_{i} / L$ は，大気境界 層全体を代表するスケーリングパラメタ $z_{i}$ を含む）。

図-6より，各流れパターンのプロットは纏まって分布 しており，Re $e_{\text {surf およびー }} / L$ によっても流れパターン が整理できると言える．尚，図-6から求めた流れ場の発 生傾向は図-8に示す.

\section{4. 結論}

1 ) ライダー観測によって得られたPPI画像を6グループ に目視で分類した. 各流れパターンの出現率を定量化し, 季節・時間・安定度などと関連づけた. Streakは全出現 パターンの半分程度を占めること，安定・静穏時に現れ やすいNo streakやThe othersも10\%程度であり，Mixedや Fish net と同程度の寄与があることが明らかになった。

2 ）各流れパターンが出現した大気場は，Reおよび $-Z_{i} / L$ で特徵づけることが可能であり，流れパターンの 出現条件を相似則パラメタ $\left(\operatorname{Reおよびー~} Z_{i} / L\right)$ によって 定量的に示した。

3）流れパターンは，地表面のローカルな大気場を表す $R e_{\text {surf }}$ およびー $z / L$ によつも分類可能であることが明 らかになった。

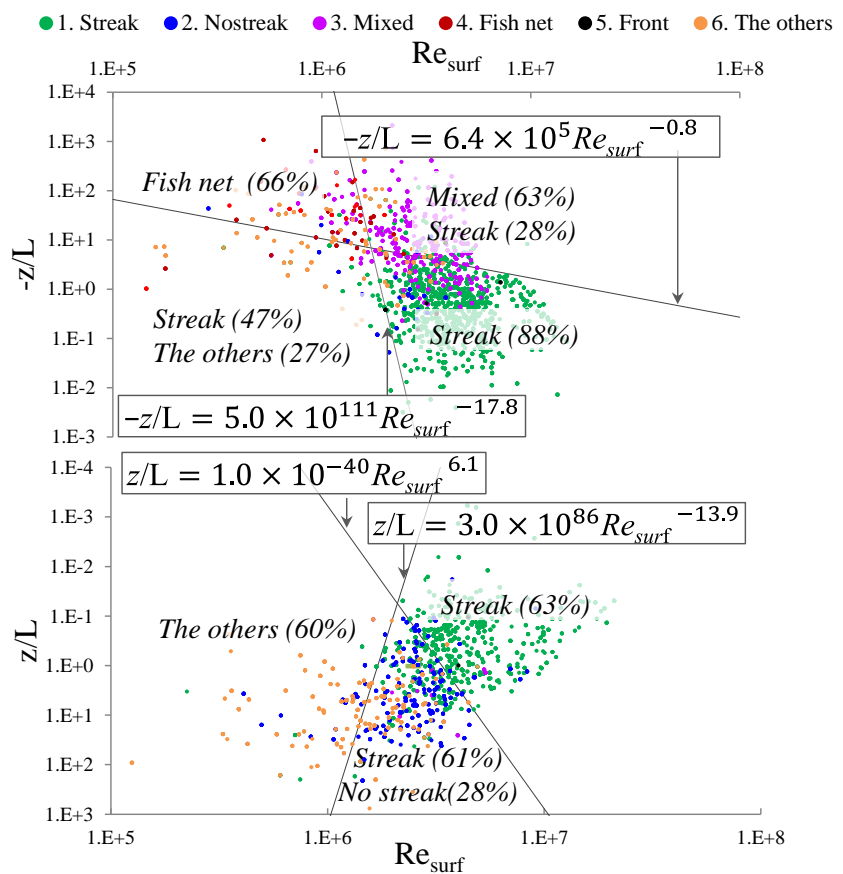

図-8 図-6から得られた流れパターンの発生傾向(点線で 各流れパターンの出現境界を，各領域内に上位の流れパ ターンおよび領域内の出現頻度を示した）

謝辞 : 本研究は文部科学省・社会システム改革と研究開発の一 体的推進「気候変動に伴う極端現象に強い都市創り」，及び科 学研究費補助金基盤研究（A）（課題番号: 25249066）による 支援を受けた。

\section{参考文献}

1) Stull, Roland B.: An introduction to boundary layer meteorology, Kluwer academic publishers, Vol. 666. pp.468-469, 1987.

2) 藤吉康志, 山下和也, 藤原忠誠 : 3 次元走査型コヒーレント ドップラーライダーによる大気境界層の流れの可視化，天気， $52.9,665-666,2005$

3)Drobinski, Philippe., FOSTER, Ralph C.: On the origin of nearsurface streaks in the neutrally-stratified planetary boundary layer, Boundary-laver meteorology, 108.2, 247-256, 2003.

4) Kanak, Katharine M., LILLY, Douglas K., SNOW, John T.: The formation of vertical vortices in the convective boundary layer, Quarterly Journal of the Royal Meteorological Society, 126.569: 2789-2810, 2000.

5)Fujiwara, C., Yamashita, K., Nakanishi, M., \& Fujiyoshi, Y.: Dust devil-like vortices in an urban area detected by a 3D scanning Doppler lidar, Journal of Applied Meteorology and Climatology, 50.3, 534-547, 2011

6) 八木綾子，有場次郎，稲垣厚至，神田 学，藤原忠誠，藤吉 康志 : ドップラーライダーによる都市上空の流れ分類, 土木 学会水工学論文集，57巻，753-758， 2013.

7) Grossman, Robert L.: An analysis of vertical velocity spectra obtained in the BOMEX fair-weather, trade-wind boundary layer, Boundary-Layer Meteorology, 23.3, 323-357, 1982.

8)近藤純正編 : 水環境の気像学一地表面の水収支・熱収支一, 朝倉書店，99-108， 1994.

9)Cohn, Stephen A., and Wayne M. Angevine.: Boundary layer height and entrainment zone thickness measured by lidars and windprofiling radars, Journal of Applied Meteorology, 39.8, 1233-1247, 2000.

10)Fujiyoshi, Y., K. Yamashita, and C. Fujiwara.: Detection of organized airflow in the atmospheric boundary layer and the free atmosphere using a 3D-scanning coherent Doppler lidar, International Symposium on Photoelectronic Detection and Imaging 2009. International Society for Optics and Photonics, 2009.

11)小田僚子，岩井宏徳，石井昌憲，関澤信也，水谷耕平，村 山泰啓 : ドップラーライダーの鉛直風速観測に基づく都市 大気境界層内乱流スケールの推定，土木学会論文集B1(水工 学), 55巻, S313-S318，2011. (2013. 9. 30受付) 